\title{
Effect of Substrate Treatment Methods on Blue Oyster Mushroom [Hypsizygus ulmarius (Bull.: Fr.) Redhead] Production
}

\author{
Pankaj Kumar Sharma*, Fateh Singh, Aman Dhawan and Surjeet Singh \\ Department of Plant Pathology, College of Agriculture, CCS Haryana Agricultural \\ University, Hisar-125004, Haryana, India \\ *Corresponding author
}

\section{A B S T R A C T}

\begin{tabular}{|c|}
\hline $\begin{array}{l}\text { Ke y w o r d s } \\
\text { Hypsizygus ulmarius, Hot } \\
\text { water, Bavistin, Formalin, } \\
\text { yield, yield parameters }\end{array}$ \\
\hline Article Info \\
\hline $\begin{array}{l}\text { Accepted: } \\
22 \text { May } 2018 \\
\text { Available Online: } \\
\text { 10 June } 2018\end{array}$ \\
\hline
\end{tabular}

Mushrooms are large reproductive structures of edible fungi belonging to Basidiomycotina. They are non-green and spore-bearing fruiting bodies of fungi which produced above ground on soil or on its food source (substrate). Blue oyster mushroom (Hypsizygus ulmarius) is one of the important edible mushroom and it was introduced for commercial production for the first time in India by Indian Institute of Horticultural Research, Bangalore (KN). This work was done to study the Influence of substrate treatment methods on yield and yield parameters and to find out the best substrate treatment methods for maximum yield. Hot water and chemicals [Bavistin (50 ppm), Formalin $(500 \mathrm{ppm})$ and Bavistin $(50 \mathrm{ppm})+$ Formalin $(500 \mathrm{ppm})]$ were employed for substrate treatment. The hot water treated substrate gave higher yield $676.2 \mathrm{~g} / \mathrm{kg}$ substrate in 2015 and $645.8 \mathrm{~g} / \mathrm{kg}$ substrate in 2016 as compared to untreated/control one with cropping duration of two months in both the cultivation seasons of $H$. ulmarius.

\section{Introduction}

Mushrooms are large reproductive structures of edible fungi belonging to Basidiomycotina. They are non-green and spore-bearing fruiting bodies of fungi which produced above ground on soil or on its food source (substrate). Blue oyster mushroom (Hypsizygus ulmarius) is one of the important edible mushroom in the world, popularly cultivated in Japan, china, North America and other Asian countries. It was introduced for commercial production for the first time in India by Indian Institute of Horticultural Research, Bangalore (KN). This mushroom closely parallels the morphology of oyster mushroom but it is far better in fruit body colour, texture, flavour and biological efficiency. Nutritionally, this mushroom contains 23.2 per cent crude protein, 56.1 per cent carbohydrates, 1.9 per cent starch and 9.1 per cent fiber on dry weight basis (Sethi et al., 2012). Medically, it is known for its cardiovascular, antitumor and cholesterol controlling properties. Mushroom can be grown on almost all lignocellulosic agriresidues which are available to the tune of more than 700 million tonnes per annum in India (Vijay et al., 2012). Growing substrate must provide the best conditions for efficient and fast colonization by the mushroom mycelium. Mushroom growth in the substrate, yield and quality can be limited by competitor 
bacteria and undesirable fungi. So growing substrates require some pre-treatment in order to eliminate harmful microorganisms and enhancing mycelium growth. One of the most important step in the preparation of mushroom growing substrate is disinfection which is known as pasteurization or sterilization. Different methods of substrate sterilization showed variation in the yield of mushroom. Therefore, the present research was undertaken to find out the most suitable method of disinfection which will be helpful for further enhancement in yield.

\section{Materials and Methods}

\section{Pure culture}

The pure culture of Hypsizygus ulmarius was obtained from Directorate of Mushroom Research (DMR), Chambaghat, Solan (HP). The pure culture was maintaned on Potato Dextrose Agar (PDA) medium and stored in a refrigerator at $4{ }^{\circ} \mathrm{C}$.

\section{Preparation of Potato Dextrose Agar (PDA) media}

Potato dextrose agar (PDA) medium was prepared by using $200 \mathrm{~g}$ peeled potato, $20 \mathrm{~g}$ dextrose and $20 \mathrm{~g}$ agar in a litre of water. Prepared media sterilized in an autoclave at 15 psi for 15 minutes.

\section{Spawn production}

Sorghum grains was boiled and then mixed with 2 per cent calcium sulphate and 0.5 per cent calcium carbonate on wet weight basis to obtain the desired $\mathrm{pH}$ of the substrates. Thereafter, these were filled in clean $250 \mathrm{ml}$ sized glass bottles, plugged with nonabsorbent cotton and sterilized at 22 psi for 2 hrs. After cooling, the bottles were inoculated with uniform sized mycelial bit of $H$. ulmarius under aseptic conditions and these inoculated bottles were incubated at $25 \pm 1{ }^{\circ} \mathrm{C}$ until complete colonization of the substrate.

\section{Substrates preparation}

The wheat straw (chopped) was used as substrate for growing of $H$. ulmarius. The substrate was soaked and covered with gunny bags overnight to acquire about 65-70 per cent moisture. For disinfecting the substrate before spawning, different substrate sterilization methods viz., hot water and chemicals were employed for substrate treatment.

\section{Hot water treatment}

In case of hot water treatment, the substrate was dipped in hot water at $60{ }^{\circ} \mathrm{C}$ for 30 minutes.

\section{Chemical treatments}

In case of chemical treatments the substrate was soaked in water containing Bavistin (50 ppm), Formalin (500 ppm) and Bavistin (50 ppm $)+$ Formalin $(500 \mathrm{ppm})$ for $16 \mathrm{hrs}$ as per the method described by Vijay and Sohi (1987).

\section{Spawning}

After draining the excess water from substrate, it was supplemented with gram flour @ 5 per cent of dry weight basis. Before spawning, the floor was cleaned with Formalin and than spawn was throughly mixed in the substrate @ 5 per cent on wet weight basis

A unit of $2.5 \mathrm{~kg}$ dry straw substrate was used for each treatment, which was equally divided in five bags representing each as replication. The spawned substrate was filled in polypropylene bags $(60 \times 30 \mathrm{~cm})$. These spawned bags were kept in mushroom house, where the relative humidity $(80-90 \%)$ were maintained by regularly spraying of water. 
Experimental design and Mushroom Cultivation

The experimental design was a randomized block design (RBD) with five replications for each treatment

The crop was taken during the month of October - December, 2015 and February April, 2016, during this period the indoor temperature varied from $20-25{ }^{\circ} \mathrm{C}$ (Figure, 1).

\section{Observation}

The observations were recorded for time taken for spawn run; pin head formation; first flush; number of flushes; number of fruiting bodies per bag; weight of fruiting bodies and yield

\section{Biological efficiency}

The yield was expressed in biological efficiency and calculated using formula (Chang et.al., 1981).

Fresh weight of mushroom Biological Efficiency = ---------------- X 100

Dry weight of substrate

The experimental data were analysed by using statistical package of program OPSTAT (2006). Critical differences (C.D.) were calculated at 5 per cent probability.

\section{Results and Discussion}

Effect of substrate treatment methods on yield and yield parameters during October - December, 2015

Among the different substrate treatment methods evaluated during crop season 2015, hot water treatment was best regarding yield but there was variations regarding the other parameters. Significantly higher yield (676.2 $\mathrm{g} / \mathrm{kg}$ substrate) was recorded in case of hot water treatment and lowest (364.8 g) (Table, 1) being in case of untreated substrate (control). The different chemical treatments also varied with respect to each-other.

Bavistin; 50 ppm (521.4 g/kg substrate) being best among the chemicals used, though it was significantly lower than hot water treatment (Table, 1).

Regarding other yield parameters viz., days for spawn run (20.2 days) (Figure, 2), pin head formation (22.2 days) (Figure, 3) and first flush (25 days) (Figure, 4); the hot water treatment also gave significantly superior results as compaired to other treatments including control.

On the other hands significant variations were observed in other parameters viz., number of flushes, number of fruit bodies and weight of fruit bodies in the different treatments.

Effect of substrate treatment methods on yield and yield parameters during February - April, 2016

Similar trend in case of yield $(645.8 \mathrm{~g} / \mathrm{kg}$ substrate) and yield parameters [days for spawn run (23.6 days), pin head formation (25.2 days) and first flush (29.4 days)] was observed during 2016 cropping period. (Table, 2).

Effect of substrate treatment methods on yield and yield parameters (pooled values of year, 2015 and 2016)

The statistical analysis of the pooled data for 2015 and 2016 revealed that the hot water treatment was most effective method of substrate treatment with positive correlation with the yield $(661 \mathrm{~g} / \mathrm{kg}$ substrate) and yield parameters [days for spawn run (21.9 days), pin head formation (23.7 days) and first flush (27.2 days)] (Table, 3 ). 
Table.1 Effect of different substrate treatment methods on yield and yield parameters during October - December, 2015

\begin{tabular}{|c|l|c|c|c|c|c|c|c|}
\hline $\begin{array}{c}\text { Sr. } \\
\text { No. }\end{array}$ & \multicolumn{1}{|c|}{ Treatment } & DFSR $^{\mathbf{1}}$ & DFPF $^{\mathbf{2}}$ & $\mathbf{D F F F}^{\mathbf{3}}$ & $\mathbf{N O F}^{\mathbf{4}}$ & $\mathbf{N O F B}^{\mathbf{5}}$ & $\begin{array}{c}\mathbf{W O F B}^{\mathbf{6}} \\
\mathbf{( g )}\end{array}$ & $\begin{array}{c}\text { Yield } \\
(\mathbf{g} / \mathbf{k g})\end{array}$ \\
\hline $\mathbf{1}$ & HWT* & 20.2 & 22.2 & 25 & 2.5 & 91.2 & 7.4 & 676.2 \\
\hline $\mathbf{2}$ & Bavistin(50 ppm) & 24.2 & 28.0 & 30.8 & 3.1 & 96.0 & 5.8 & 554.8 \\
\hline $\mathbf{3}$ & Formalin(500ppm) & 29.4 & 34.0 & 37.8 & 1.8 & 93.2 & 4.5 & 418.0 \\
\hline $\mathbf{4}$ & $\begin{array}{l}\text { Bavistin(50ppm)+ } \\
\text { Formalin(500ppm) }\end{array}$ & 26.0 & 29.6 & 32.6 & 3.1 & 106.7 & 4.7 & 501.6 \\
\hline $\mathbf{5}$ & Control & 33.2 & 38.4 & 42.2 & 1.2 & 89.9 & 4.0 & 364.8 \\
\hline $\mathbf{6}$ & CD $(0.05)$ & 1.9 & 1.5 & 1.4 & 0.5 & 1.7 & 0.3 & 30.3 \\
\hline
\end{tabular}

*Hot water treatmen

Figures in parentheses are angular transformed values

1: Days for spawn run, 2: Days for pinhead formation, 3: Days for first flush, 4: Number of flushes, 5: Number of fruit body per bag, 6: Weight of fruit body

Table.2 Effect of different substrate treatment methods on yield and yield parameters during February - April, 2016

\begin{tabular}{|c|c|c|c|c|c|c|c|c|}
\hline $\begin{array}{l}\text { Sr. } \\
\text { No. }\end{array}$ & Treatment & DFSR $^{1}$ & $\mathrm{DFPF}^{2}$ & DFFF $^{3}$ & $\mathrm{NOF}^{4}$ & $\mathrm{NOFB}^{5}$ & $\begin{array}{c}\text { WOFB }^{6} \\
(\mathrm{~g})\end{array}$ & $\begin{array}{l}\text { Yield } \\
(\mathrm{g} / \mathrm{kg})\end{array}$ \\
\hline 1 & HWT* & 23.6 & 25.2 & 29.4 & 3.7 & 99.8 & 6.9 & 645.8 \\
\hline 2 & Bavistin(50 ppm) & 25.0 & 30.6 & 33.0 & 2.9 & 95.4 & 5.5 & 521.4 \\
\hline 3 & Formalin $(500 \mathrm{ppm})$ & 30.8 & 32.4 & 36.0 & 1.8 & 95.0 & 4.3 & 402.9 \\
\hline 4 & $\begin{array}{l}\text { Bavistin }(50 \mathrm{ppm})+ \\
\text { Formalin(500ppm) }\end{array}$ & 28.0 & 31.6 & 34.0 & 3.1 & 113.8 & 4.1 & 470.4 \\
\hline 5 & Control & 34.8 & 39.2 & 44.4 & 1.9 & 94.4 & 3.8 & 354.2 \\
\hline 6 & $\mathrm{CD}(0.05)$ & 2.6 & 1.8 & 2.2 & 0.3 & 5.7 & 0.9 & 50.5 \\
\hline
\end{tabular}

*Hot water treatment

Figures in parentheses are angular transformed values

1: Days for spawn run, 2: Days for pinhead formation, 3: Days for first flush, 4: Number of flushes, 5: Number of fruit body per bag, 6: Weight of fruit body

Table.3 Effect of different substrate treatment methods on yield and yield parameters (pooled values of year, 2015 and 2016)

\begin{tabular}{|c|c|c|c|c|c|c|c|c|}
\hline $\begin{array}{l}\text { Sr. } \\
\text { No. }\end{array}$ & Treatment & DFSR $^{1}$ & $\mathrm{DFPF}^{2}$ & DFFF $^{3}$ & $\mathrm{NOF}^{4}$ & NOFB $^{5}$ & $\begin{array}{c}\mathrm{WOFB}^{6} \\
(\mathrm{~g})\end{array}$ & $\begin{array}{l}\text { Yield } \\
(\mathrm{g} / \mathrm{kg})\end{array}$ \\
\hline 1 & HWT* & 21.9 & 23.7 & 27.2 & 3.2 & 95.5 & 6.9 & 661 \\
\hline 2 & Bavistin(50 ppm) & 24.6 & 29.3 & 31.9 & 3.1 & 95.7 & 5.6 & 538.1 \\
\hline 3 & Formalin(500ppm) & 30.1 & 33.2 & 36.9 & 1.9 & 94.1 & 4.3 & 410.5 \\
\hline 4 & $\begin{array}{l}\text { Bavistin }(50 \mathrm{ppm})+ \\
\text { Formalin }(500 \mathrm{ppm})\end{array}$ & 27.0 & 30.6 & 33.3 & 3.2 & 110.2 & 4.4 & 486.0 \\
\hline 5 & Control & 34.0 & 38.8 & 43.3 & 1.6 & 92.1 & 3.9 & 359.4 \\
\hline 6 & $\mathrm{CD}(0.05)$ & 1.9 & 1.1 & 1.3 & 0.3 & 2.5 & 0.4 & 33.0 \\
\hline
\end{tabular}

*Hot water treatment

Figures in parentheses are angular transformed values

1: Days for spawn run, 2: Days for pinhead formation, 3: Days for first flush, 4: Number of flushes, 5: Number of fruit body per bag, 6: Weight of fruit body 
Fig.1 Weather parameters during cropping period of Hypsizygus ulmarius

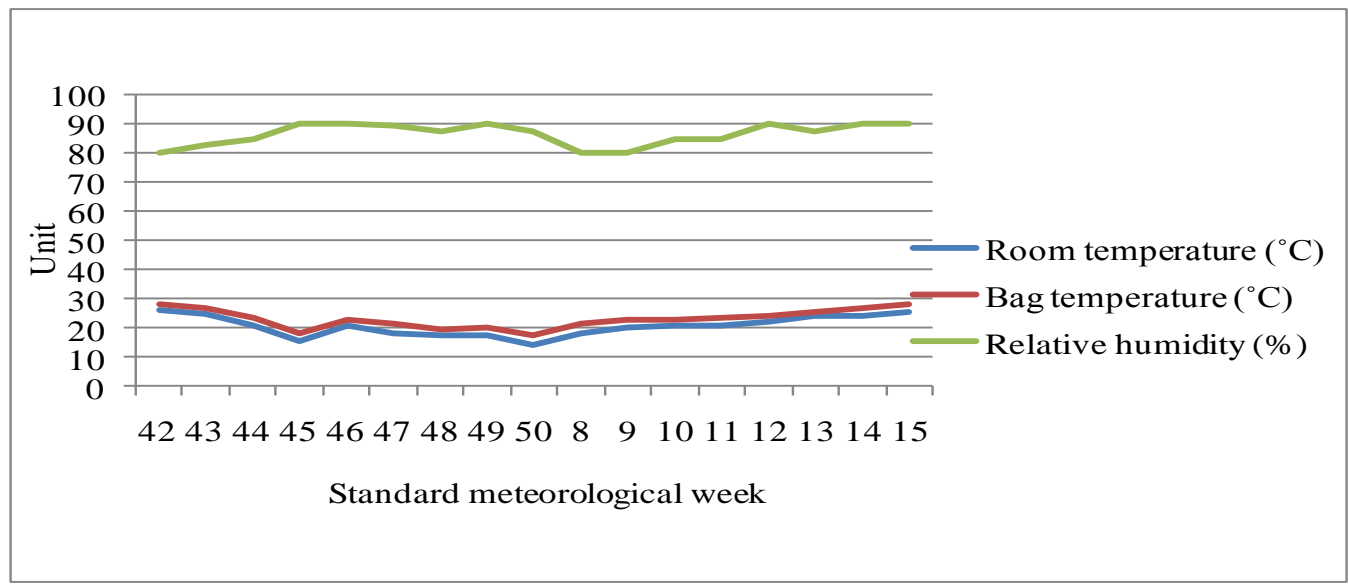

Fig.2 Spawn run of Hypsizygus ulmarius

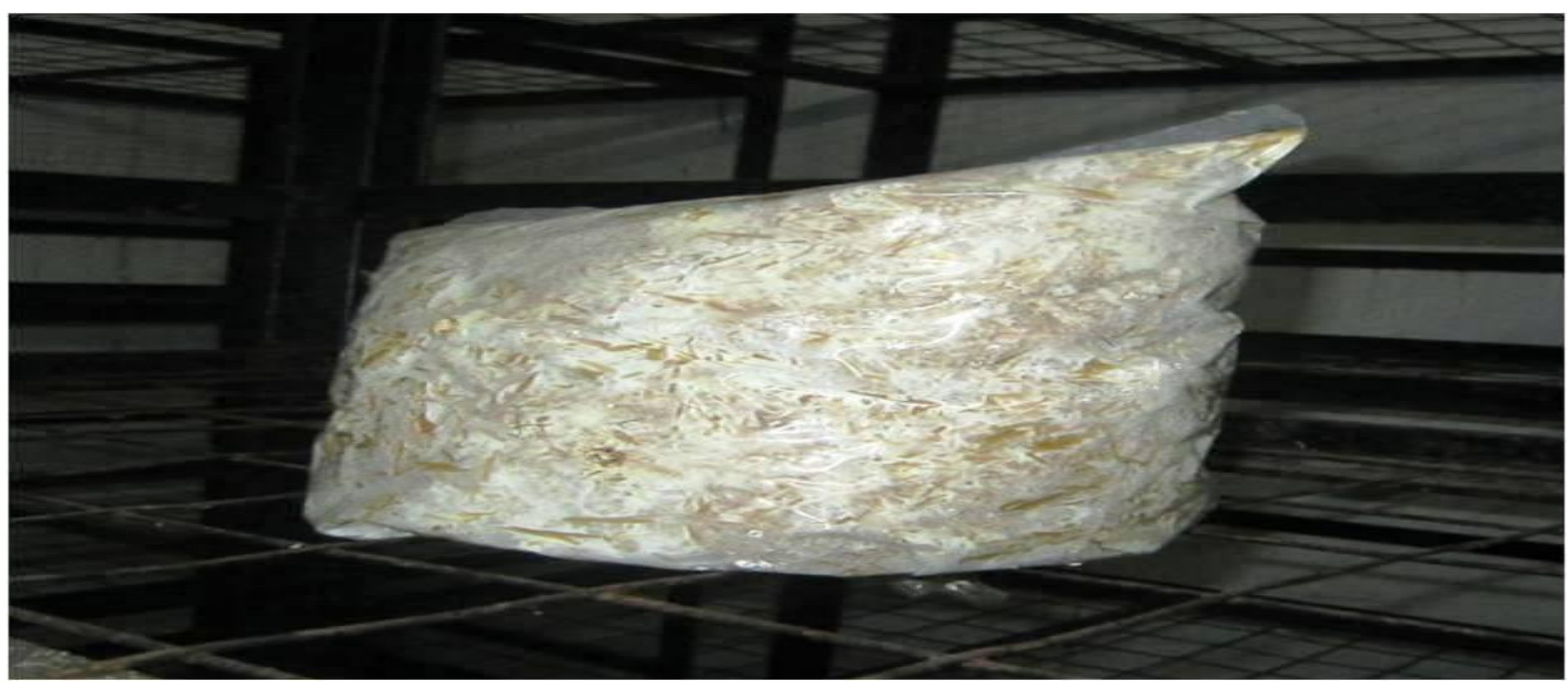

Fig.3 Pin head formation of Hypsizygus ulmarius

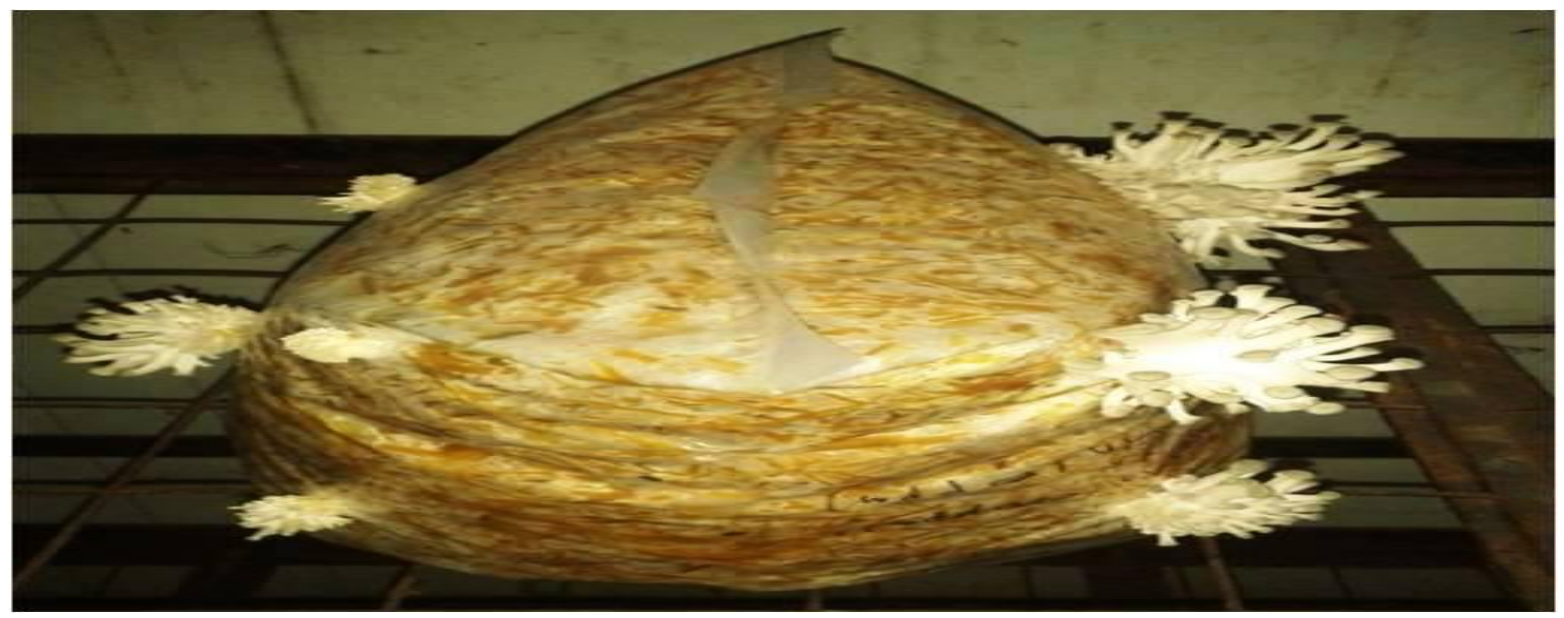


Fig.4 Appearance of first flush of Hypsizygus ulmarius

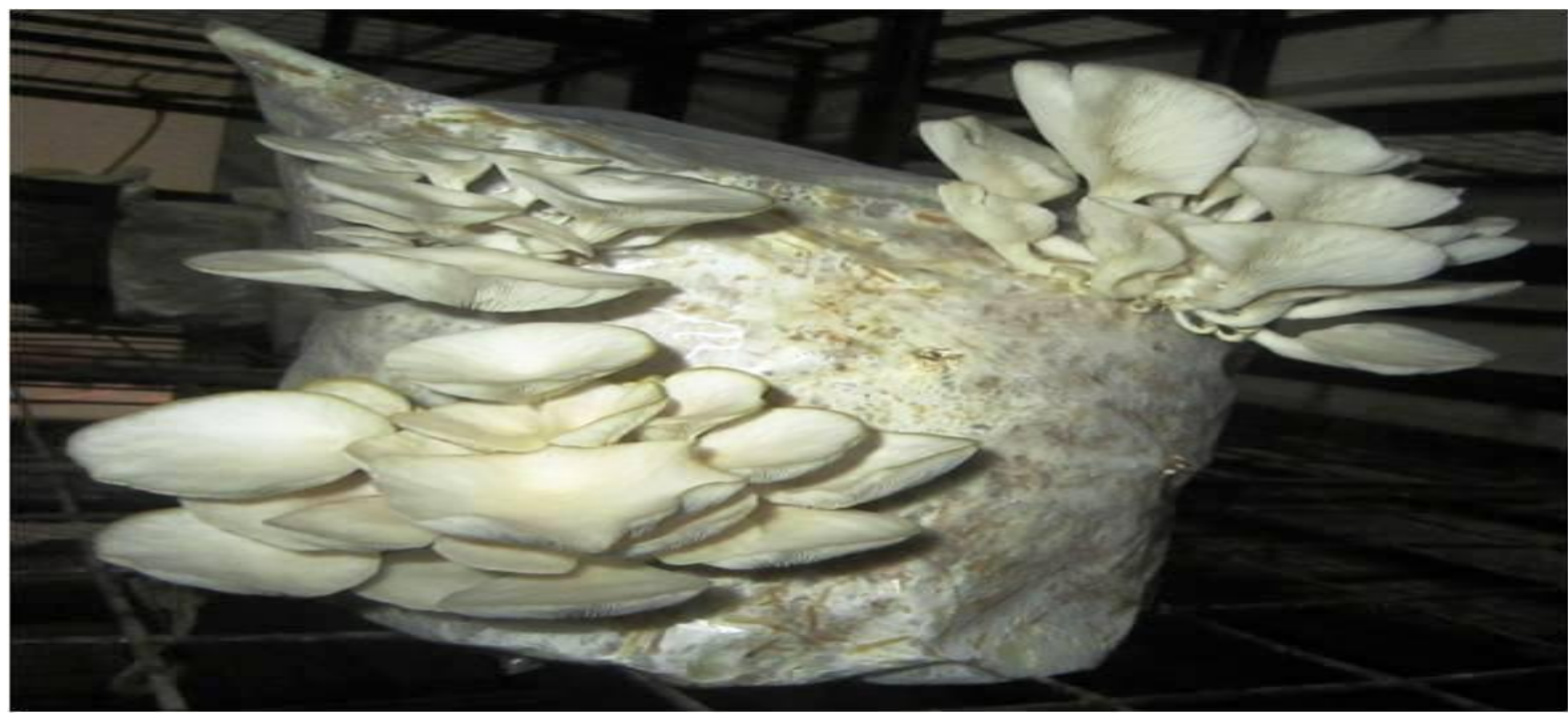

The mushroom was cultivated using wheat straw and the substrate was supplemented with 5 per cent gram flour. H. ulmarius was cultivated during October-December, 2015 and February-April, 2016. The results revealed that substrate treatment methods influenced the yield parameters. The yield of this mushroom increased from 364.8 (control) to $676.2 \mathrm{~g}$ (hot water treatment), $554.8 \mathrm{~g}$ (Bavistin; $50 \mathrm{ppm}$ ), $418 \mathrm{~g}$ (formalin; 500 $\mathrm{ppm}$ ) and $501.6 \mathrm{~g} / \mathrm{kg}$ substrate (bavistin; 50 ppm + formalin; 500 ppm) during 2015 and a similar trend was also observed during 2016 cropping period.

This work is in agreement with that of Sethi et al., (2012) who reported that spawn run period was minimum in hot water treated substrate in comparision to the chemical treatments and hot water treated substrate gave better yield and biological efficiency in comparision to the chemical treatments. On the other hand, Oseni et al., (2012) also reported that hot water treatment at $60^{\circ} \mathrm{C}$ for 3 hrs. was best treatment method for oyster mushroom.

It is inferred from the above discussion that, Hot water treated wheat straw supplemented with 5 per cent gram flour spawned with sorghum grains based spawn gave three flushes of $H$. ulmarius with a biological efficiency of 66.10 per cent.(Table, 3 )

\section{Acknowledgments}

A feeling of sincere and heartfelt gratitude envelops me as I draft this acknowledgement. I acknowledge my esteemed Major Advisor, advisory committee, Head, Department of Plant Pathology, faculty members and nonteaching staff of Department of Plant Pathology for their willing cooperation and sagacious guidance rendered during the course of the investigation.

\section{References}

Chang, S.T., Lau, O.W. and Cho, K.Y., 1981. The cultivation and nutritive value of Pleurotus sajor-caju. European Journal of Applied Microbiology and Biotechnology. 12: 58-62.

Oseni, T. O., Dlamini, S. O., Earnshaw, D. M. and Masarirambi, M. T., 2012. Effect of substrate pre-treatment methods on oyster mushroom (Pleurotus ostreatus) 
production. International Journal of Agriculture and Biology. 14(2): 251.

Sethi, S., Sodhi, H.S., Dhanda, S. and Kapoor, S., 2012. Cultivation of blue oyster mushroom, Hypsizygous ulmarius (Bull.) Redhead in Plains of Northern India. Indian Journal of Ecology. 39(2): 195- 199.

Sethi, S., Sodhi, H.S., Kapoor, S. and Khanna, P.K., 2012. Nutritional and mineral profile of blue oyster mushroom, Hypsizygus ulmarius (Bull.). Journal of Research Punjab Agricultural University. 49(4): 256-258.
Sheoran, O. P., Online statistical analysis tool (OPSTAT), 2006. www.hau.ernet.in/ about/opstat.php. CCSHAU, Hisar.

Vijay, B. and Gupta, Y., 2012. Production technology of Agaricus bisporus. Advances in Horticulture. 33: 66-88.

Vijay, B. and Sohi, H.S., 1987. Cultivation of oyster mushroom Pleurotus sajor-caju (Fr.) Singer on chemically sterilized wheat straw. Mushroom Journal of Tropics. 7: 67-75.

\section{How to cite this article:}

Pankaj Kumar Sharma, Fateh Singh, Aman Dhawan and Surjeet Singh. 2018. Effect of Substrate Treatment Methods on Blue Oyster Mushroom [Hypsizygus ulmarius (Bull.: Fr.) Redhead] Production. Int.J.Curr.Microbiol.App.Sci. 7(06): 3367-3373. doi: https://doi.org/10.20546/ijcmas.2018.706.395 